\title{
Changes of Adenohypophysial RNA, Plasma ACTH activity and Plasma Corticosterone following various acute stimuli in Rats
}

\author{
H. YASUI, M. OIMOMI, Y. KOHOZUKI, M. HIGASHI, \\ H. TANIGUCHI, S. ITOH and S. TSUJI
}

IInd Department of Internal Medicine, School of Medicine, KobeUniversity Kobe, Japan

It has not yet been confirmed whether pituitary synthesis of ACTH is actually accelerated under conditions of acute stimuli, or not.

In order to clarify this problem, adenohypophysial RNA, which seems to reflect the intensity of protein synthetic activity, plasma ACTH activity and plasma corticosterone were simultaneously determined after various acute stimuli in rats.

Adenohypophysial RNA was determined by Schmidt-Thaunhauser-Schneider's method based on the spectrophotometric measurement of liberated pentose by orcinol reaction.

Plasma ACTH activity was measured by an in Vitro bioassay using beef adrenocortical slices which was developed in our clinic.

DeMoor's fluorophotometric method was employed for measurement of plasma corticosterone.

The results were summarized as follows:

1). Adenohypophysial RNA content in female rat was slightly higher than in male, but this difference was not statistically significant, : the value was $5.26 \pm 0.23 \mu \mathrm{g} / \mathrm{mg}$ of tissue and $4.39 \pm 0.18 \mu \mathrm{g} / \mathrm{mg}$ in male, respectively.

2). Plasma ACTH activity reached to the highest level at $\mathrm{t} 5 \mathrm{~min}$. after ether-vapour exposure and therafter declined to control level, but plasma corticosterone reached its highest level at $30 \mathrm{~min}$. after ether. Adenohypophysial RNA content increased significantly at 60 and $120 \mathrm{~min}$. after ether-exposure, their value before the ether and at 60 and $120 \mathrm{~min}$. after were $4.68 \mu \mathrm{g} / \mathrm{mg}, 6.24 \mu \mathrm{g} / \mathrm{mg}(\mathrm{P}<0.01)$ and $7.17 \mu \mathrm{g} / \mathrm{mg}(\mathrm{P}<0.02)$, respectively.

3). Pituitary RNA, plasma ACTH activity and plasma corticosterone were determined at intervals of 2.5 to 120 min. following laparotomy. Plasma ACTH began to increase at $2.5 \mathrm{~min}$. following incision and continued to stay on its high level up to $120 \mathrm{~min}$.

Adenohypophysial RNA did not increase rapidly after laparotomy, but it increased significantly at 60 and $120 \mathrm{~min}$. following incision. Pituitary RNA content before incision, at 2.5, 60 and $120 \mathrm{~min}$. after incision were $4.29 \mu \mathrm{g} / \mathrm{mg}, 5.68 \mu \mathrm{g} / \mathrm{mg}(\mathrm{n} . \mathrm{s}),. 7.15 \mu \mathrm{g} / \mathrm{mg}(\mathrm{P}<$ $0.01)$ and $5.80 \mu \mathrm{g} / \mathrm{mg}(\mathrm{P}<0.05)$, respectively.

4). The changes of adenohypophysial RNA content, plasma ACTH activity and plasma corticosterone were observed at intervals of 2.5 to $60 \mathrm{~min}$. following intra-venous 
administration of Lysine-8-Vasopression (100mU/100gm) into tail vein. Plasma ACTH activity was significantly increased at $2.5 \mathrm{~min}$. after injection, but $15 \mathrm{~min}$. later it returned to control level.

Changes of adenohypophysial RNA following L-8-V administration were not so remarkable as compared with changes following ether or laparotomy as above mentioned. Actual adenohypophysial RNA content before L-8-V injection, at 2.5 and $60 \mathrm{~min}$. after injection were $3.75 \mu \mathrm{g} / \mathrm{mg}, 4.55 \mu \mathrm{g} / \mathrm{mg}$ (n.s.), and $5.22 \mu \mathrm{g} / \mathrm{mg}(\mathrm{P}<0.5)$, respectively.

5). The effect of intermittent bell-ringing continued for $30 \mathrm{~min}$. on adenohypophysial RNA, plasma ACTH activity and plasma corticosterone was investigated. All of these indices were significantly increased after bell-ringing. RNA content changed from 4.69 $\mu \mathrm{g} / \mathrm{mg}$ of control value to $6.13 \mu \mathrm{g} / \mathrm{mg}(\mathrm{P}<0.05)$ after bell-ringing.

6). As summary, following conclusion could be drawn. Various kinds of stimuli applicated in this report seems to mobilize the endogenous hypothalamic CRF (Corticotrophin Releasing Factor).

The next response is the rapid increase of plasma ACTH activity within 2.5 to $5.0 \mathrm{~min}$., which is to be correlated to the release of ACTH from pituitary, for extended periods of certain time interval.

The increase of adenohypophysial RNA, which is postulated as to reflect the increase of ACTH synthesis, appeared relatively in later period as compared with the increase of plasma ACTH.

(pp. 754 759) 


\title{
急激な刺激負荷後の下垂体前葉内 RNA 含量と血漿中 $\mathrm{ACTH}$ 活性の変動に関する研究
}

\author{
神戸大学 辻内科 \\ 安井 博和, 老粐 宗忠, 上月 祥生 \\ 谷口洋, 東 宗則, 伊藤 節子 \\ 辻昇三
}

(昭和43年 8 月 30 日受付)

研究の目的：諸種刺激に対する下垂体よりの AGTH 放出態度と下垂体内での蛋白合成の観察より AGTH 分泌機序の解明を試みた.

方法 : 急激な刺激負荷後の下垂体内 RNA 含量と Plasma AGTH 活性の変動を測定した。

成績 : 刺激負荷後 Plasma AGTH は急激に增加するが，下垂体内 RNA 含量は，早期には変動せ ず，60分目に最高となつた.

結論: 刺激負荷後急激な ACTH 放出がまず起とり, 遅れて下垂体内 RNA 含量が增加する.

\section{1) 緒言}

蛋白合成における RNA の占める重要性については衆知である。下垂体内 ACTH 合成機構の解析にも, RNA の変動を通して研究した Hess 等 ${ }^{1)}$ Kraicer 等2)の報告がある. 一方諸種の急激な外部環境変化に対応 して，急激な下垂体よりの ACTH 放出現象が存在する ${ }^{3)}$ 事が認められ，てのAGTH 放出の前段階とし て視床下部 GRF (Gorticotropin Releasing Factor) の動員がまず起てる事も確められている4)5)。この様 な急激な放出現象の中で，合成機転の関与の有無についてはまだ意見が一定していない，ての事は一方では 下垂体よりの Trophic Hormone の放出因子と称せられている視床下部性 Releasing Factor が合成にも 関与するのかどうかという争点にも通ずる問題である，著者らは, Schmidt-Thaunhauser-Schneider 法6) にて下垂体内 RNA 含量を測定し，同時に血漿中 AGTH 活性; 血漿中 Corticosterone を“いわゆる Stress” 下に於ける白鼠について測定し，二，三の興味ある知見を得たので報告する.

\section{2) 方法と材料}

a) : 体重 100-150gm のWistar 系純系白鼠を用いた。性差については後述の検討をした結果より, 特に 区別しなかつた。また白鼠は実験に供する 1 週間前より研究公にて一定条件下で飼育された。

\section{b) : RNA の測定}

断頭後直ちに開頭し，下垂体前葉のみを皮冷せる生食水にて三度洗浄し，附着せる血液成分を充分取除き， 重量を測定後, 承泠せる蒸溜水にて Homogenize を行なう。一つの実験群について 2 〜 前葉をプールした. Homogenize 後水冷せる 10\% T.C.A. 老添加, 2500回転10分間遠沈する. 上清を除き， 10\% T.C.A. 亿て再洗浄後， $1 \mathrm{ml}$ の蒸溜水中に晸濁し，99\% Ethanol を加光て㩭拌2500回転，10分間遠沈 して，上清を捨てる．以後その沈渣を Ether : Ethanol の 1：3の混合液にて 3 回洗浄し脂質成分を除去す る. 最後の Sediment Fraction に $0.6 \mathrm{~N}$ の KOH を添加して $37^{\circ} \mathrm{C} 20$ 時間 Incubation した後に, Orcinol 反応にて，遊離した 5 炭糖を测定し，それによつて RNA を定量するのである。比色計は Beckman 型 Photometer にて波長は $660 \mathrm{~m} \mu$ とした. RNA 含量は $\mu \mathrm{g} / \mathrm{mg}$ of tissue にて表現されている。なお標準 
RNA には市販の醭母性 RNA（和光）を用いた。

以上の Procedure は Fig. 1 に示されている.

Fig. 1. Determination of RNA in pituitary gand

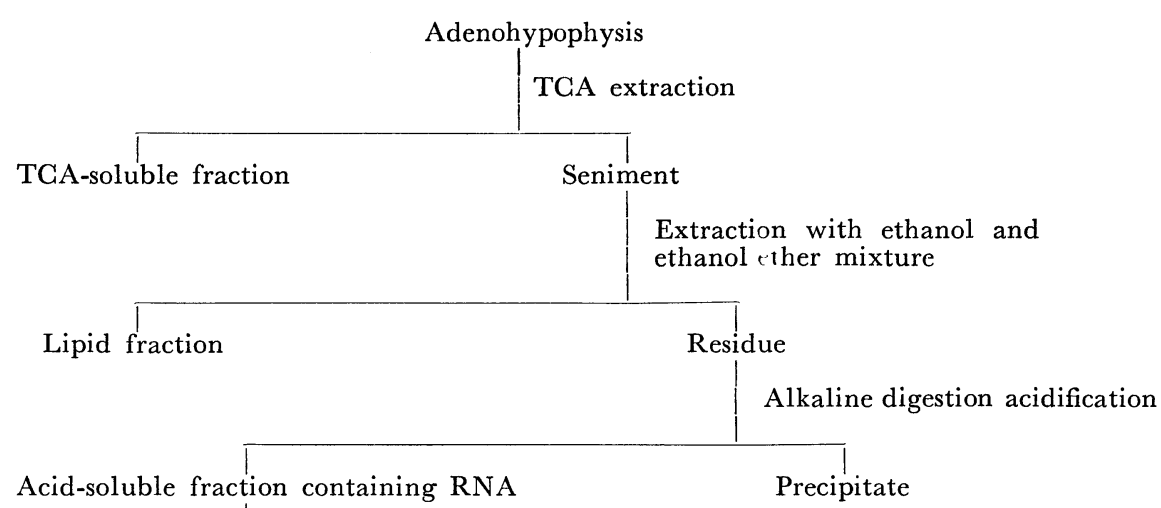

Orcinol reagent Heating in boiling water

Read at $660 \mathrm{~m} \mu$

Schmidt, Thanhauser \& Schneider method (1946)

\section{c) : ACTH 活性の測定}

血漿中の ACTH 活性の測定については著者の一人がすでに詳述している778) 牛副腎皮質薄片を使用する in vitro-Bioassay 法を用いた。 4 倍稀釈の血漿を medium にして，牛副婜皮質薄片と接触させ90分間の Incubation 後に medium 内に放出された steroids を硫酸螢光比色法にて測定するもので，血槳中に含ま れる AGTH 活性の表現は $\mu \mathrm{g} / \mathrm{gm} / \mathrm{ml}$ でなされている。即ち $1 \mathrm{ml}$ の新鮮検体血漿が牛副腎皮質 $1 \mathrm{gm}$ 当 りに何 $\mu \mathrm{g}$ の steroids を放出させるかをもつて表わしている。血漿中の AGTH 活性を測定する場合は, 同一検体についてフラスコを $3 \sim 4$ ケ用意し，1 ケのフラスコには副腎皮質薄片は添加せずに 4 倍血漿稀釈 液のみを入れ，残りの $2 \sim 3$ ケのフラスコには副腎皮質薄片を添加する。乙れは一種の盲検とも称されるも ので血漿 $1 \mathrm{ml}$ に含まれる螢光度を, Incubation 後の medium 内に release された steroids の螢光度か ら差引く為である，本法はすでに報告しているでとく ${ }^{8)}$ ，同時に多量の検体を同一の Assay 系で処理し うる利点がある事より，我々は常に double 或は triple Trial を施行している.

d) : 血獎中 Corticosterone

血漿中 Corticosterone は De Moor 等9)による Fluorophotometric Method によつた。

\section{3）結果}

\section{i ) 下垂体前葉 RNA 含量の雌・雄差について}

Table 1. 亿示すは体重 100-150gm の雌・雄無処置白鼠を午前 8〜9時の間に断頭殺した場合の下垂体 RNA 含量である.

推計学的処理を施せば雌・雄に有意な差は認められないが, 雌は19例平均で $5.26 \pm 0.23$ (S.E.) $\mu \mathrm{g} / \mathrm{mg}$ of tissue 雄は 15 例平均が $4.39 \pm 0.81 \mu \mathrm{g}$ of tissue とやや雌の方が多い僋向である.乙れは下垂体一副腎皮質系

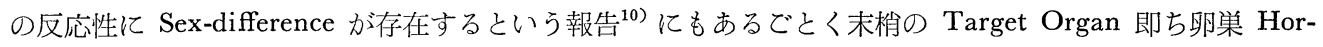
mone の影響が二次的に下垂体内の RNA 含量にも影響を及ぼしているとも考光られる。雌・雄の性差は 推計学的には認められなかつたが，以下の実験に於ては，同一実験群は同一性を用いるようにした。 
ii）刺激負荷後の RNA の変動：

(1) : Ether-Vapour-Stimulus

Fig. 2, Table 2. 亿於て Ether 負荷後の血漿中 $\mathrm{ACTH}$ 活性, 血漿中 Corticosterone, 下垂体内 RNA の変動を示した. Ether Vapour に1〜1.5 分間爆露すれば白鼠は完全に麻酔状態に入る，その 状態加ら 5 分，15分，30分，60分，120分の各時点 で AGTH 活性と Corticosterone を, 又, 15分, 60分，120分の各時点で RNA を測定した. AGTH 活性は Fig. 2 より明らかな様に 5 分後に最高值とな り 30 分後には完全に前值に戾り，120分後に迄同様 の状態が続くが，血中 Corticosterone は ACTH 活性より遅れて30分後に最高值になり60分後に前值 に戻る。一方 RNA 含量は前值の $4.68 \mu \mathrm{g} / \mathrm{mg}$ から 15分後に $5.68 \mu \mathrm{g} / \mathrm{mg} .60$ 分後に $6.24 \mu \mathrm{g} / \mathrm{mg}, 120$ 分 後に $7.17 \mu \mathrm{g} / \mathrm{mg}$ と上昇し, 60 分後, 120 分後は前值 に比して $\mathrm{p}<0.01, \mathrm{p}<0.02$ と夫々有意に増加してい る.

\section{(2) : Laparotomy-Stimulus}

Pentobarbital-Na $(5 \mathrm{mg} / 100 \mathrm{gm})$ を腹腔内注射後 15分目に腹部正中切開を加え, それ以後 2 分 30 秒目, 15分目, 60 分目, 120 分目の ACTH 活性, Corti costerone, RNA を測定した. 開腹後60分, 120分 目に断頭する群には, 開腹部位が空気に直接触れな い様に湿潤した生食水ガーゼをその傷口に当てた。 ACTH 活性, Corticosterone の反応性は先述の Ether-Stimulus とは趣を異にしている事がわか る. 即ち刺激後 2 分 30 秒目にすでに上昇を始めた

Fig. 2. Effect of ether vapour on plasma ACTH and plasma corticosterone

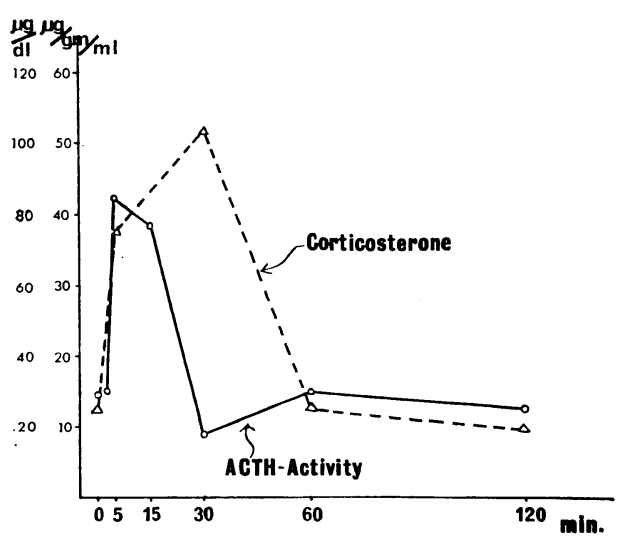

Table 1. Sex difference of adenohypophyseal RNA in rat

\begin{tabular}{|c|c|c|}
\hline Exp. No. & Male & Female \\
\hline 1. & 4.50 & $4.08 \begin{array}{l}\mu \mathrm{g} / \mathrm{mg} \text { of } \\
\text { adenohypophysis }\end{array}$ \\
\hline 2. & 4.70 & 4.73 \\
\hline 3. & 3.92 & 4.86 \\
\hline 4. & 6.22 & 4.28 \\
\hline 5. & 2.64 & 4.27 \\
\hline 6. & 3.98 & 7.40 \\
\hline 7. & 3.77 & 4.86 \\
\hline 8. & 3.29 & 5.05 \\
\hline 9. & 3.97 & 5.71 \\
\hline 10. & 5.94 & 4.91 \\
\hline 11. & 4.58 & 3.56 \\
\hline 12. & 4.33 & 6.21 \\
\hline 13. & 3.90 & 6.07 \\
\hline 14 . & 4.67 & 6.22 \\
\hline 15. & 5.93 & 4.35 \\
\hline 16. & & 6.87 \\
\hline 17. & & 5.52 \\
\hline 18. & & 5.41 \\
\hline 19. & & 5.70 \\
\hline Mean & 4.39 & 5.26 \\
\hline$\pm \mathrm{S} . \mathrm{E}$. & 0.81 & 0.23 \\
\hline
\end{tabular}

Statisticaly : Not significant between male and female

AGTH 活性は15分後になお高值に達し, 60分後, 120分後にその高值が持続する. 一方 Corticosterone は 2 分 30 秒目にはまだ上昇が認められない が，15分後に最高值に達し，同様に高值が持続し ている. 一方 RNA含 量は前置の $4.29 \mu \mathrm{g} / \mathrm{mg}$ が 60分後には $7.15 \mu \mathrm{g} / \mathrm{mg}, 120$ 分後には $5.80 \mu \mathrm{g} / \mathrm{mg}$ と何れも有意に増加を認めた。 結果は Fig. 3, Table 3 に示した.

Table 2. Ghanges of pituitary RNA content after ether vapour $\mu \mathrm{g} / \mathrm{mg}$ of tissue

\begin{tabular}{c|c|c|c|c}
\hline & before & $15 \mathrm{~min}$. & $60 \mathrm{~min}$. & $120 \mathrm{~min}$. \\
\hline \hline $\begin{array}{c}4.68 \\
\pm 0.34\end{array}$ & $\begin{array}{c}5.68 \\
\pm 0.38\end{array}$ & $\begin{array}{c}6.24 \quad * 1 \\
\pm 0.17\end{array}$ & $\begin{array}{r}6.17 \quad * 2 \\
\pm 0.88\end{array}$ \\
\hline Exp. No. & 5 & 5 & 4 & 4 \\
\hline$* 1 \mathrm{p}<0.01 \quad * 2 \mathrm{p}<0.02$
\end{tabular}


Fig. 3. Effect of laparotomy on plasma ACTH and plasma corticosterone

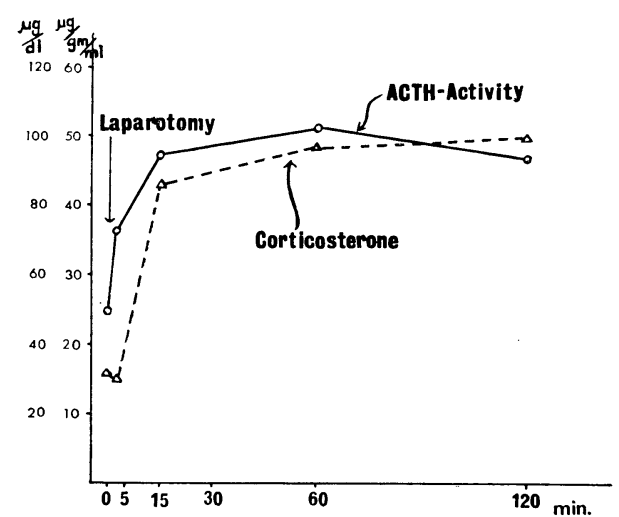

Fig. 4. Effect of Lys-8-Vasopressin (100mU/ $100 \mathrm{gm}$ i.v.) on plasma ACTH and plasma corticosterone

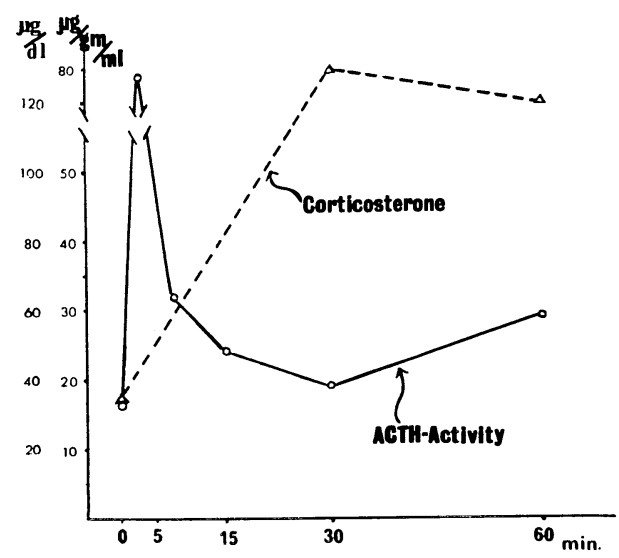

Table 3. Ghanges of pituitary RNA content after laparotomy $\mu \mathrm{g} / \mathrm{mg}$ of tissue

\begin{tabular}{c|c|c|c|c|c}
\hline \hline & before & $2.5 \mathrm{~min}$. & $15 \mathrm{~min}$. & $60 \mathrm{~min}$. & $120 \mathrm{~min}$. \\
\hline \hline \begin{tabular}{c|c|c|c|c|}
4.29 \\
\pm 0.22
\end{tabular} & $\begin{array}{c}5.68 \\
\pm 0.57\end{array}$ & 6.00 & $\begin{array}{r}7.15 * 1 \\
\pm 0.46\end{array}$ & $\begin{array}{r}5.80 * 2 \\
\pm 0.47\end{array}$ \\
\hline Exp. No. & 5 & 6 & 2 & 5 & 6 \\
\hline$* 1 \mathrm{p}<0.01 \quad *^{2} \mathrm{p}<0.05$
\end{tabular}

Table 4. Change of pituitary RNA content after Lys-8-Vasopressin $(100 \mathrm{mU} / 100$ gmi.v.) $\mu \mathrm{g} / \mathrm{mg}$ of tissue

\begin{tabular}{l|c|c|c}
\hline & before & $2.5 \mathrm{~min}$. & $60 \mathrm{~min}$. \\
\hline & $\begin{array}{c}3.75 \\
\pm 0.02\end{array}$ & $\begin{array}{c}4.55 \\
\pm 0.37\end{array}$ & $\begin{array}{r}5.22 * \\
\pm 0.81\end{array}$ \\
\hline Exp. No. & 5 & 4 & 5 \\
\hline
\end{tabular}

* slightly significant

\section{(3) : Lys-8-Vasopressin-Administrations}

Pentobarbital-Na (5mg/100gm) を腹腔内投与後15分目に，Lys-8-Vasopressin (100mU/100gm) を尾静 脈より投与し， 2 分 30 秒， 7 分，15分，30分，60分目の ACTH 活性と Corticosterone，並びに 2 分 30 秒， 60分目の RNA を測定した. ACTH 活性，並びに Corticosterone は Fig. 4 より明らかな様にまず著明な ACTH 活性の上昇が認められ, 遅れて Corticosterone の上昇が認められる. AGTH 活性は30分後には前 值に復する。一方 RNA 含量は Table 4 に示した如く前值の $3.75 \mu \mathrm{g} / \mathrm{mg}$ から 60 分後に $5.22 \mu \mathrm{g} / \mathrm{mg}$ と推計 学的にはそれ程有意ではないが増加の傾向が認められた.

\section{(4) : Ether-Laparotomy-Stimulus}

この場合の刺激負荷方法は, Ether 麻酔後直ちに開腹し, 腹膜に切開が及んだ後再び直ちに縫合して放置 し， 2 時間後に断頭殺したものである. Ether Vapour 単独負荷では，Fig. 2 で示した様に60分後にすでに AGTH 活性, Corticosterone 值は前值に復している状態である. 又 Laparotomy 単独負荷の場合と異な り, 切開部位を直ちに縫合して腹腔内容が直接空気へ爆露されない条件下である. Table 5 に示した如く, 
ACTH 活性は Control に比してまだ増加の傾向にあり, Corticosterone は著明に増加している.一方 RNA 含量も前值の $4.68 \mu \mathrm{g} / \mathrm{mg}$ より 2 時間後には $6.54 \mu \mathrm{g} / \mathrm{mg}$ と推計学的に有意に増加を認めた.

\section{(5) : Bell-Ringing-Stimulus}

白鼠のケーヂ内に大型ベルを入れた状態で30分間放置した群を Control とし，そのベルを間歇的に30分 間ならしたものを刺激群とした．即ち30分間ベルをならした後直ちに断頭殺した場合であるが，Table 6 に 示した如く, AGTH 活性, Corticosterone はいずれも有意の増加を認め, 一方 RNA 含量も Control の $4.69 \mu \mathrm{g} / \mathrm{mg}$ から $6.13 \mu \mathrm{g} / \mathrm{mg}$ とやはり有意に増加を認めた.

Table 5. Effect of 2 hours after ether-laparotomy on pituitary RNA, plasma ACTH and plasma corticosterone

\begin{tabular}{c|c|c|c|c}
\hline \hline & Exp. No. & $\begin{array}{c}\text { Pituitary RNA } \\
\mu \mathrm{g} / \mathrm{mg}\end{array}$ & $\begin{array}{c}\text { Plasma ACTH } \\
\mu \mathrm{g} / \mathrm{gm} / \mathrm{ml}\end{array}$ & $\begin{array}{c}\text { Plasma corticosterone } \\
\mu \mathrm{g} / \mathrm{dl}\end{array}$ \\
\hline \hline $\begin{array}{c}\text { Control } \\
\text { mean } \pm \text { S.E. }\end{array}$ & 5 & $\begin{array}{c}4.68 \\
\pm 0.34\end{array}$ & $\begin{array}{c}20.82 \\
\pm 1.90\end{array}$ & $\begin{array}{c}51.2 \\
\pm 1.60\end{array}$ \\
\hline $\begin{array}{c}\text { Ether-Lap. } \\
\text { mean } \pm \text { S.E. }\end{array}$ & 6 & $\begin{array}{c}6.54 \\
\pm 0.72\end{array}$ & $\begin{array}{c}30.72 \\
\pm 3.91\end{array}$ & $\begin{array}{c}81.9 \\
\pm 5.75\end{array}$ \\
\hline
\end{tabular}

* $\mathrm{P}<0.01$

Table 6. Effect of bell-ringing on pituitary RNA, plasma ACTH and plasma corticosterone

(Intermittent bell-ringing was continued for 30 minutes)

\begin{tabular}{c|c|c|c|c}
\hline \hline & Exp. No. & $\begin{array}{c}\text { Pituitary RNA } \\
\mu \mathrm{g} / \mathrm{mg}\end{array}$ & $\begin{array}{c}\text { Plasma ACTH } \\
\mu \mathrm{g} / \mathrm{gm} / \mathrm{ml}\end{array}$ & $\begin{array}{c}\text { Plasma corticosterone } \\
\mu \mathrm{g} / \mathrm{dl}\end{array}$ \\
\hline \hline $\begin{array}{c}\text { Control } \\
\text { mean } \pm \text { S.E. }\end{array}$ & 6 & $\begin{array}{c}4.69 \\
\pm 0.64\end{array}$ & $\begin{array}{c}17.34 \\
\pm 1.13\end{array}$ & $\begin{array}{c}27.80 \\
\pm 3.83\end{array}$ \\
\hline $\begin{array}{c}\text { Bell ringing } \\
\text { mean } \pm \text { S.E. }\end{array}$ & 6 & $\begin{array}{c}6.13 \\
\pm 0.38\end{array}$ & $\begin{array}{c}34.99 \\
\pm 3\end{array}$ & $\begin{array}{c}*^{2} \\
\pm 1.30\end{array}$ \\
\hline$*^{1} \mathrm{P}<0.05$ & $*^{2} \mathrm{P}<0.01$ & &
\end{tabular}

\section{4) 考按}

急激な外部環境変化に適応して下垂体からの急峻な ACTH 放出が起てる事は, Verniko-Dannelis ${ }^{3)}$, 老籷 ${ }^{4)}$ 等によりすでに報告されている。乙の下垂体前葉からの ACTH 放出現象に，下垂体内での ACTH 合成 が関与しているのかどうか，或は関与しているならばどの時期に関与しているのか等の問題に関して現在未

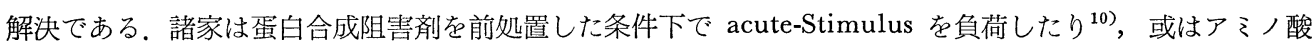
に Radio Isotope を labell したものを前投与した後に acute-Stimulus を加え，そのアミノ酸の下垂体内 ACTH 分画への incorporation の変化の解析 ${ }^{11)}$ をしたりするととによつて，この acute-Stimulus の状態 下での “分泌”の背景の“合成”を問題として取上げている。乙の事は帰納的にいえば，内因性の CRF が 単なる放出因子なのか，或は合成にも関与する因子なのかという点に連続するものである，即ち acute-Stimulus 負荷短時間後に視床下部中央隆起部の内因性 GRF の活性が著增する ${ }^{4) 5)}$ が，一方その様な条件下で やはり迅速に血漿中 AGTH 活性の上昇が認められ，引続いて血漿中 Corticosterone の上昇が認められる。 その様な連続せる反応様式の中で下垂体内の AGTH そも何等かの変化が来るであろうと推測されるのは当 然である. その変化を “合成”の問題の level で捕えるには下垂体内での AGTH の存在形式 ${ }^{12) 13)}$ に焦点 を当てるべきだと思われる，著者等の指標の一つとして採用した RNA は，いう迄もなく蛋白合成機転の 
核となるものであり, 従つてその増加は蛋白合成機転充進を意味する事も又自明である。しかしながら刺激 負荷後の一定時間後に上昇した RNA-level をみたとしても，てれがたと血漿中 ACTH，血墏中 Corticosterone の上昇に連続している変化であつても，それが直ちに下垂体内での ACTH 合成の增加を意味す ると断定しうる特異性はない. Estep 等 ${ }^{10)}$ も ${ }^{14} \mathrm{C}-$ Valine を投与した直後に Laparotomy-Stimulus を負 荷し, 刺激後30分，60分，120分の各時点で下垂体前葉の T.C.A. precipitate 群への ${ }^{14} \mathrm{C}-$ Valine の incorporation を観察し，時間の経過と共に incorporation の増加が認められる事を述へ，ACTH 合成の断面 を捕え得た事を報告している，著者らの実験でも，用いられた諸種の刺激負荷後，60分目に下垂体内前葉 RNA が最高となつている. Ether-Stimulus, 或は Lys-8-Vasopressin 投与等の場合の様に血漿中 ACTH 活性が負荷後早期に上昇するが短時間内に前值に復するパターンをとる場合には，ACTH 活性が上昇して いる時期に RNA の増量は認められず，遅れて増加を来す。一方 Ether-Laparotomy 後 2 時間目, Bell-30 分間負荷後, Pentobarbital-Laparotomy 後60分目というょうに刺激がある時間連続的に負荷されている状 態では ACTH 活性は持続的な上昇を来し，血漿中 ACTH 活性が高值である時期に RNA が増加してい る. 刺激負荷の方法によつて下垂体からのAGTHの放出パターンに差があり, 従つて下垂体内での AGTH の動員の様式にも差があると推祭されるが，RNA の増加がある一定時間後でないと認められないというと とは興味ある点である. 即ち刺激負荷後, その刺激によつて動員された内因性 CRF が直接下垂体内 RNA の増量の方に作用したとするよりは，動員された内因性 CRF がまず下垂体からの biological active な ACTH の放出に作用し, RNA が増加するのはての放出の結果二次的に起とる現象と解される.

ACTH の放出現象があれば，それに相応した合成機序の関与があつて下垂体内での ACTH に平衡関係 が成立している事は当然考朰られる。しかしその機序の解明の為にまずなされねばなら好事は下垂体内での ACTH の存在形式の研究であらう.

\section{5) 結華}

Wistar 系白鼠を用いて，下垂体前葉内 RNA 合量と血漿中 AGTH 活性の変動を諸種の acute-Stimulus 負荷後について検討した。

i ）下垂体前葉内 RNA 含量の雌雄差は統計学的には有意でないが，雌の方がやや多い.

ii ) Ether Vapour, Laparotomy, Ether-Laparotomy, Bell-Ringing, Lys-8-Vasopressin 等の acuteStimulus によつて下垂体前葉内 RNA は負荷後早期には上昇せず，60分目に最高值をとる。

iii）刺激負荷によつて動員された視床下部内 GRF は下垂体前葉よりの AGTH 放出に作用する事が第一 義的であり, 下垂体前葉内 RNA の增量はその結果として起こる現象と解釈した.

iv) Ether Vapour 1 分負第, Lys-8-Vasopressin 投与等では血漿中 ACTH は一過性に上昇し, 連続し て血漿中 Corticosterone も同様に一過性に上昇し，短時間内に前值に復するが，Laparotomy 負荷，或は Bell-Ringing 30分間負荷等では持続せるACTH 活性の上昇が認められる.刺激負荷の方法によつてACTH の放出のパターンに差があると推察された.

（本論文の要旨は第 7 回日本医学会シンポジゥム（於：盛岡：1968，7）に於て著者の一人によつて発表 された.)

\section{文献}

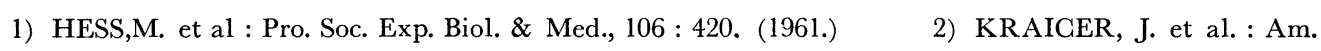
J. of Physiology, $214:$ 158, (1968). 3) VERNIKOS-DANELLIS, J. : Endocrinology, 72 : 574, (1963). 4) 老粐宗忠：日本内分泌学会雑誌揭載予定. 5) 広重 力：第17回日本医学会学術講 演集, III : 318, (1967). 6) SCH NEIDER, W.C. : J.B.C., $164: 747,(1946) . \quad 7$ ) 安井博和 : 日本内分泌学会䧴誌, $41: 643,(1965)$. 8) 辻, 安井等 : 綜合臨床, $17: 742,(1968)$. 9) DeMOOR, P. et al : Acta Endocrinologica. $33: 297$, (1960). 10) ESTEP, H. et al : Endocrinology, $80: 719$, (1967). 11) JACOBOWITZ, D. et al : Endocrinology, $72: 592$, (1963). 12) GURRIE, A.R. et al : Acta Endocrinologica, $42: 69$, (1963). 13$)$ DASGUPTA, P.R. et al : Acta Endocrinologica, $53: 31$, (1967). 